\title{
Methods and means for the in-house training of mining machine operators
}

\author{
Vladimir Velikanov ${ }^{1, *}$, Natalja Dyorina $^{1}$, and Azat Abdrakhmanov ${ }^{1}$ \\ ${ }^{1}$ Nosov Magnitogorsk State Technical University, Magnitogorsk, Russia
}

\begin{abstract}
This study investigates the quality issue of the in-house training process for mining machine operators. The authors prove the urgency of the designated problem. The changes in modern society, as well as the development of science and technology have a direct impact on the vocational education system. This paper describes the main aspects of the in-house training process of mining machine operators; define the essence, structure, contents, and main directions of its revitalization. The following solutions are proposed in order to improve the quality of the in-house training process: to use the original method based on a rating system of the operator knowledge evaluation, active and interactive forms of using modern training technologies. The authors conducted testing techniques in mining enterprises with the aim of confirming the adequacy of the suggested approaches. The results are given in the work. It was proposed that the methods and tools integration has a positive impact on professional training system.
\end{abstract}

\section{Introduction}

Raising the population's welfare is known to depend critically upon the economy growth ensure, which is inextricably connected with its human potential. The "Doctrine of the Russian Federation National Security" states a high level of education quality as one of the most important elements of the country national security [1]. This fact implies overcoming the Russian Federation scientific, technical, and technological dependence on external sources, market expansion, and faster growth of high-tech products, the financial and material resources concentration in priority areas of science and technology.

To date, the production sphere enterprises have a substantial innovative potential, but they cannot implement it due to insufficient quantity, quality, and sometimes the lack of specialists having the necessary knowledge and mastering the latest technology that meet the needs of the age.

The mining industry is known to be one of the most promising and strategically important sectors of the Russian economy. In accordance with the "Energy Strategy of Russia for the period till 2030», mining should reach a fundamentally new level of its development [2]. It has been demonstrated that it is necessary to solve a number of issues in order to achieve these goals. They include weak development of the Russian mining machinery and growing industry dependence on imported technology and equipment, physical and moral deterioration of production assets, which in turn determines the less satisfactory profitability of the mining industry and productivity, great losses in the raw material processing and extraction. The other problems can be described as highenergy intensity of the production, as the lack of new formation specialists, who are able to quick and adequate development of the technique and technology, by providing growth of new advanced competencies. The work has emphasized that eliminating the imbalance between supply and demand of labor to solve the professional and qualifying tasks can be added to the list of problems.

About 490-500 units mining shovels and hydraulic excavators are in operation on the large iron ore quarries of Russia and the CIS, and $90 \%$ of them are the cars made by domestic producers (PO "Uralmash", "IS CARTEX", PA "Izhora Works", and others.). Furthermore, $80 \%$ of the total fleets of excavators are the shovels with a bucket of 5-10 m3, released back in the 80 s of the last century. It was found that the share of mining equipment of foreign production in 2012 were less than $5 \%$ (in amount) $[3,4]$.

Excavator fleet status indices for the coal industry are given in Table. 1 [5].

Table 1. Excavator fleet status for the coal industry in the whole

\begin{tabular}{|c|c|c|c|}
\hline \multirow{2}{*}{$\begin{array}{l}\text { № } \\
\Pi / \Pi\end{array}$} & \multirow[t]{2}{*}{ Excavator model } & \multicolumn{2}{|c|}{ Amount, item } \\
\hline & & $\begin{array}{c}\text { on } \\
\text { stock }\end{array}$ & $\begin{array}{l}\text { in } \\
\text { work }\end{array}$ \\
\hline 1. & Domestic brand excavators & 1254 & 1113 \\
\hline 2. & in percent, at hand & 100 & 88,8 \\
\hline 3. & Foreign brand excavators & 233 & 205 \\
\hline 4. & in percent, at hand & 100 & 88,0 \\
\hline 5. & $\begin{array}{l}\text { total }=\text { domestic brand excavators }+ \\
\text { foreign brand excavators }\end{array}$ & 1487 & 1318 \\
\hline 6. & in percent, at hand & 100 & 89 \\
\hline 7. & $\begin{array}{l}\text { domestic brand excavators in percent } \\
\text { as percentage of total }\end{array}$ & 15,7 & 15,6 \\
\hline
\end{tabular}

${ }^{*}$ Corresponding author: rishik_00@mail.ru 
In 2016, it is planned to increase the total volume of iron ore, as well as an increase in coal production, which implies an increase in the annual volume of overburden operations.

In light of this, it can be assumed that a significant increase of quarries and open pits mined rock throughput can be achieved by the technical re-equipment of the parks with modern samples of domestic excavation equipment of the new generation of CMMS (crawler mounted mining shovel)-12K, CMMS -18P, CMMS $32 \mathrm{R}$, as well as those made by foreign manufacturers Hitachi (Japan), Komatsu (Japan), Kobelko (Japan), Caterpillar (the USA) etc. Therefore, the open cast mining needs human resources, relevant for the qualification requirements of modern technologies of mining and equipment in order to achieve high productivity.

The need for a change of approaches in the field of the recruitment policy has been reflected in the "Development Strategy of Labor Training System and of Applied Qualifications Formation in the Russian Federation for the period till 2020" (hereinafter - the Strategy), which defines the main sustainable directions of the state policy in the field of skilled workers (employees) and mid-level professionals training in Russia [6].

The Strategy declares that a significant trend in the development of organizations and enterprises personnel potential is the creation of their own centers and personnel training programs. In common, this situation corresponds to the global trend of increasing the role of employees' in-house training at the premises of corporate training centers.

Furthermore, it has been suggested that the staff inhouse development is the most important factor of the enterprise long-term success. The process of the management system organization in the field of training for mining companies involves the development and implementation of corresponding recruitment policy at each enterprise. Its main areas must become the following ones: to identify the needs of the enterprise in the labor force both in its quantity and in quality; to introduce the definite measures for improvement in professional skills use and increase; to monitor the quality of training; to develop the further in-house training path, taking into account the current labor market and the specifics of the mining industry.

The training center of an enterprise is created in the structure of its staffing services and is a new type of an intra-school. Its main tasks include the organization of skilled workers training with a focus on specifics and the main directions of the production process development, as well as taking into consideration the existing level of the student training.

However, some unresolved problems remain: the low prestige of the training system for the labor and the applied qualifications; the system imbalance and lack of the vocational education system reaction to changes in the labor market; lack of the qualified personnel, caused by the general demographic situation in the Russian Federation; lack of regulatory and methodical documents defining the professional skills, experience and professional education requirements.

The presence of the unresolved problems made it possible to determine the aim of the work: the control system organization in the field of labor training for the mining industry should be oriented to increasing the inhouse training efficiency of mining machinery and transport-technological complexes operators. The aim decomposition is illustrated in Figure 1.

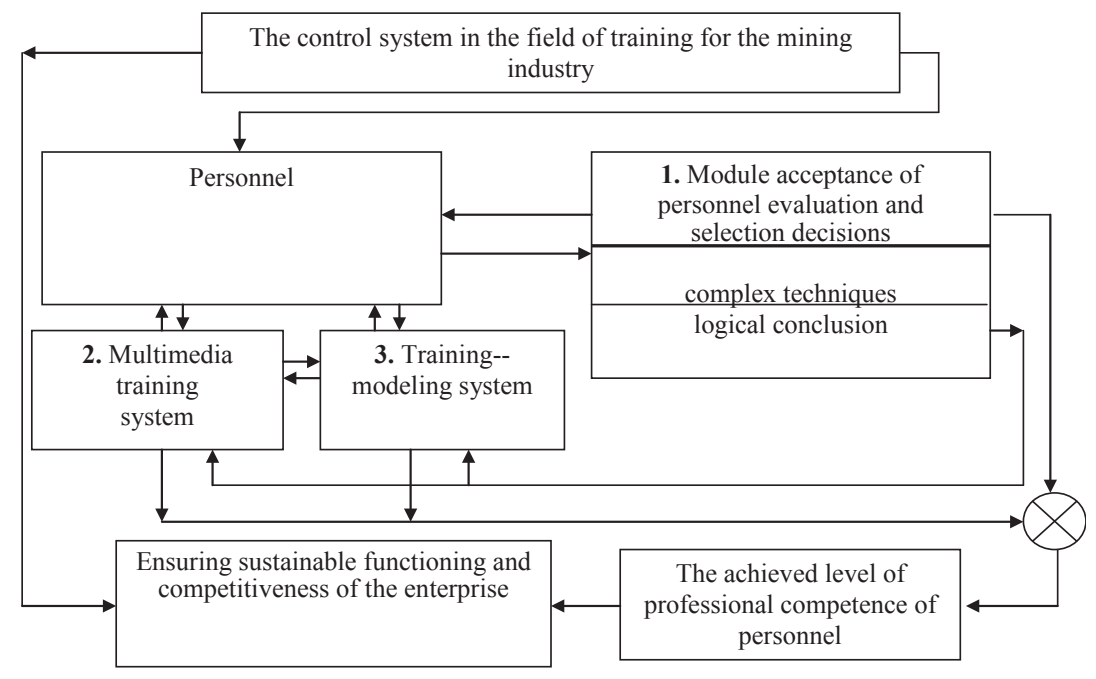

Fig. 1. The aim decomposition.

It is necessary to solve the following tasks in order to achieve the aim of this study:

1. To carry out the set-theoretic analysis of the training systems structures for identifying the specifics of mining machinery and transport-technological complexes operators training.
2. To develop the functional structure of the informationanalytical control system in the field of the personnel training, tools for its implementation and the operation evaluation.

3. To develop a quantifying evaluation method of important indicators showing the readiness level of 
mining machinery and transport-technological complexes operators, where the indicators affect the professional activity efficiency.

4. To design and implement a multi-functional training facility for mining machine and transport-technological complexes operators training.

5. To use the developed system of mining machinery and transport-technological complexes operators training by trial and to evaluate the system effectiveness.

The investigation underlines that the Russian Federation training technologies are intensively evolving in the aerospace, military, aviation, chemical industry, in the preparation of the operational personnel for electric power facilities, as well as simulators for technological equipment are developed in construction and mining.

The traditional teaching method for fueling machine operators is known to be the exercises on real hardware. However, when being trained on real fueling machines, difficulties may arise in the implementation of such important principles of learning as phasing and continuity; there is no objective control and self-control action of a student's correctness. It must be emphasized that high-performance equipment is diverted from the production process and it wears out in the course of training, further power consumption happens [7].

It should be noted that the term "refueling machine" is quite applicable to the considered cyclical mining excavators. For an operational cycle an excavator performs the following operations: dredging (cutting and filling the bucket); deducing the bucket with soil from the bottom; moving the bucket filled with soil to the place of unloading; unloading soil from the bucket to the dump or into a vehicle; bucket movement (swing) to the bottom; lowering the bucket to prepare for the next step of digging [7]. Additionally, it is demonstrated in Figure 2 that in accordance with the classifications transport and loading machines belong to the same group - the moving and transport-technological systems.

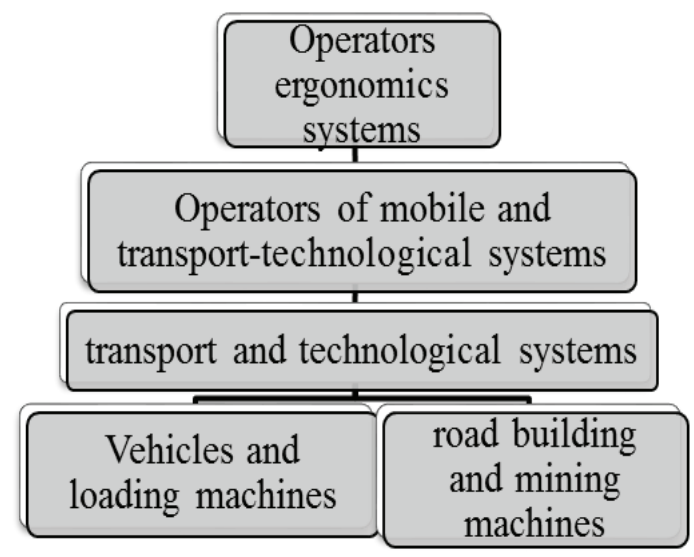

Fig. 2. Classification of the ergonomic systems operators.

The scientific literature presents a technique to assess the effectiveness of the simulators use in the personnel training (Table. 2)

Table 2. Evaluation of training facilities

\begin{tabular}{|c|c|c|}
\hline Application Area & Author & Dependence \\
\hline $\begin{array}{l}\text { engineering and manufacturing } \\
\text { systems }\end{array}$ & $\begin{array}{l}\text { R.A. Fayzrakhmanov, I.S. } \\
\text { Polevshchikov [7] }\end{array}$ & $\begin{array}{l}\text { The researchers calculate comprehensive assessment of } \\
\text { the level of operators professional skills formation, based } \\
\text { on the use of fuzzy sets theory }\end{array}$ \\
\hline electrical power engineering & $\begin{array}{l}\text { S.I. Magid, } \\
\text { I.SH. Zagretdinov, } \\
\text { L.P. Muzyka [8] }\end{array}$ & $\begin{array}{c}\mathrm{P}_{\mathrm{ob}}=\mathrm{P}_{\mathrm{cy}} \mathrm{P}_{\text {int }} \mathrm{P}_{\text {inf }} \mathrm{P}_{\text {mat }} \mathrm{P}_{\mathrm{erg}} \mathrm{P}_{\mathrm{ps} x} \\
\mathrm{P}_{\mathrm{cy}} \text { - adequacy of objectives and circumstances, } \\
\mathrm{P}_{\text {int }}-\text { interior adequacy, } \\
\mathrm{P}_{\text {inf }} \text { - information adequacy, } \\
\mathrm{P}_{\text {mat }} \text { - the adequacy of mathematical modeling, } \\
\mathrm{P}_{\text {erg }} \text { - ergonomic adequacy, } \\
\mathrm{P}_{\mathrm{ps}}-\text { psychological adequacy }\end{array}$ \\
\hline aviation industry & L.A. Proshkina [9] & $\begin{array}{c}K=K_{0}+\left(\mathrm{a} K_{1}+\mathrm{b} K_{2}+\mathrm{c} K_{3}\right) \\
K-\text { efficiency ratio of the simulator, } \\
\mathrm{K} 0-\text { coefficient, taking into account the initial level of } \\
\text { training, } \\
\mathrm{K} 1, \mathrm{~K} 2, \mathrm{~K} 3-\text { coefficients, taking into account, } \\
\text { respectively, knowledge and skills, } \\
\text { a, b, c - weights }\end{array}$ \\
\hline
\end{tabular}

Changes in the structure and composition of the excavator fleet, the introduction of modern technologies of mining operations and the increase in mining operations are determined by the need to update the content and quality of the mining machinery and transport-technological complexes operators training.
Furthermore, for the successful operation, mining enterprises should not only have high technical equipment and qualified staff in order to make effective use of its production facilities.

The authors have examined the issue of results appraisal of in-house training based on the developed technique with the aim of specifying further studies [1014]. 


\section{Methodology}

The range of professional activity tasks were defined owing to the analysis of the operators labor activities (for example, drivers of career dredges), to the study of the technological regulations and instructions requirements for mining machinery and transport-technological complexes, owing to accounting expert opinions. The authors suggested assessing the quality of training and simulator training of operators on the generalized criteria - the activity efficiency coefficient $\left(\mathrm{k}_{e f}\right)$. The procedure includes three main components: an analysis of the components that make up the structure of the production activities of operators; evaluation of each group, and the indicators that determine the production efficiency; forming the preliminary report and analyzing the results.

The procedure involves the following steps:

1. The procedure of classification groups and the distribution of key indicators in the group that determine the effectiveness of the operator's activity. The first group includes the kind of activity defining "professional skills" of an excavator operator - $\mathrm{Pi}$, the second one includes "theoretical knowledge».

2. Carrying out the importance estimation of groups and indicators within the group.

3. Rationing the key indicators.

4. Expert information collection and processing monitoring cards processing.

5. Effectiveness coefficient determination of the mining machinery and transport and technological complexes operators.

6. The results analysis and the preliminary report formation.

In accordance with the obtained efficiency coefficient, a decision is made by the team leader (the decision maker) (Table 3).
Table 3. Rules of adopting decisions on the bases of $\mathrm{k}_{э ф}$.

\begin{tabular}{|c|c|c|}
\hline Values $k_{\ni \phi}$ & $\begin{array}{l}\text { Operator } \\
\text { Readiness } \\
\text { level }\end{array}$ & Ergatic system state \\
\hline $\begin{array}{c}0,75< \\
k_{\ni \phi}<0,9\end{array}$ & High & $\begin{array}{l}\text { mining machine } \\
\text { control at a high level } \\
(\mathrm{HL}) \quad-\quad \text { high } \\
\text { performance }(\mathrm{HP})\end{array}$ \\
\hline $\begin{array}{c}0,55< \\
k_{\text {э }}<0,75\end{array}$ & Average & $\begin{array}{l}\text { Mining machine } \\
\text { control at a sufficient } \\
\text { level (SL) }- \text { high } \\
\text { performance }(\mathrm{HP})\end{array}$ \\
\hline $\begin{array}{c}0,35< \\
k_{\ni \phi}<0,55\end{array}$ & Lowered & $\begin{array}{l}\text { Mining machine } \\
\text { control at a } \\
\text { satisfactory level (SL) } \\
-\quad \text { Low performance } \\
\text { (LP) }\end{array}$ \\
\hline$k_{\ni \phi}<0,35$ & Low & $\begin{array}{l}\text { Mining } \\
\text { control at a critical } \\
\text { level (CL) - Low } \\
\text { performance (LP) }\end{array}$ \\
\hline
\end{tabular}

\section{Results}

Methodology testing was carried out at the mining enterprises of the Southern Urals. The total amount of sampling for the experimental verification was obtained in the survey $n=400$ excavator drivers.

The monitoring results illustrated that promising ones are the operators with experience of 5-10 years, from the point of view of the performance of their production functions, as the received and earned value of theoretical knowledge, backed by achieved skills, allow to realize the potential of machinery and to ensure performance in compliance with specifications (Fig. 3).

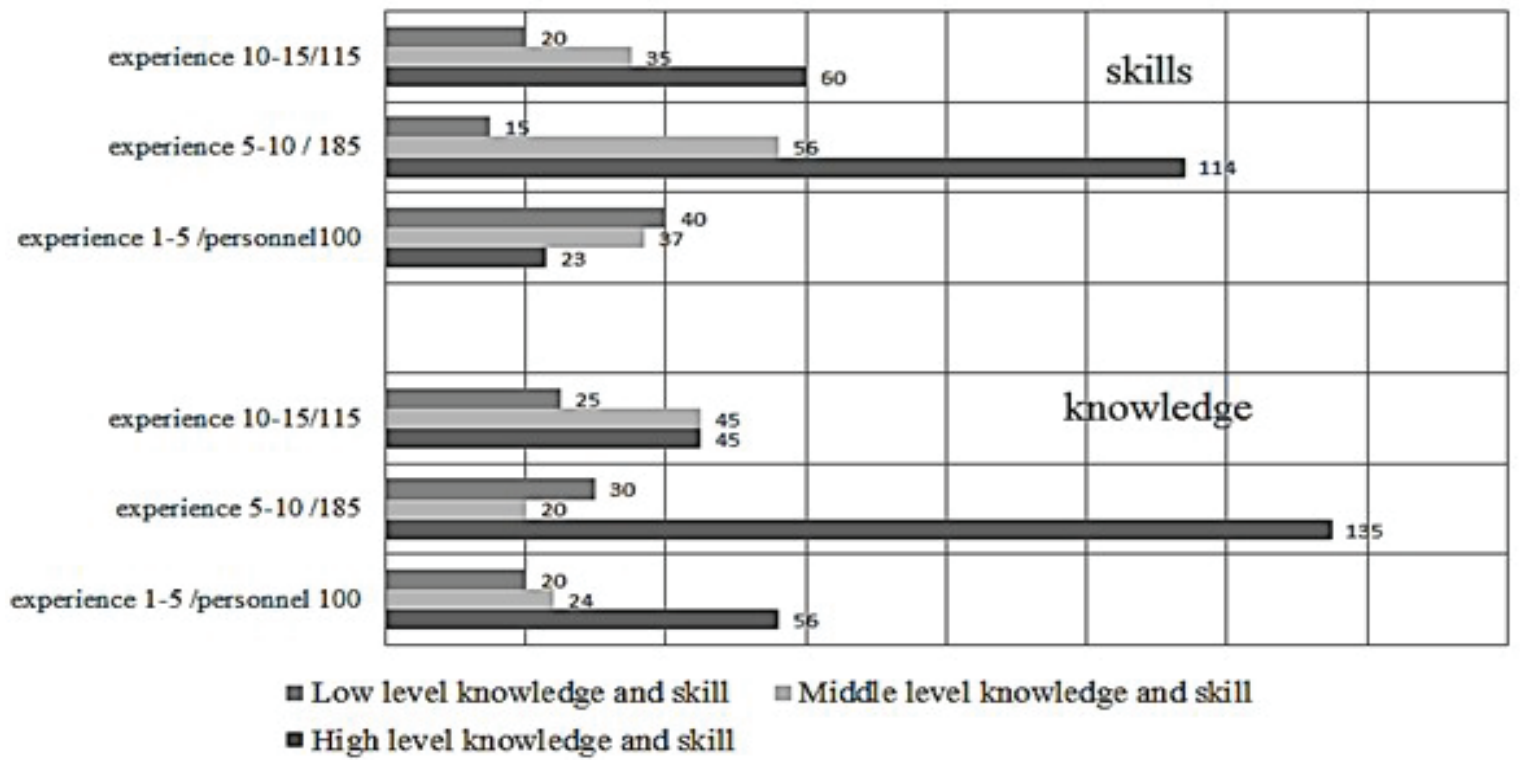

Fig.3. Final results of the evaluations for excavator drivers distribution into groups that determine the operation efficiency. 


\section{Conclusion}

1. It was found that the change in the excavator park structure, modernization and improvement of technical and operational characteristics of the machines, the introduction of modern mining operations technologies lead to a shortage of the professional staff, and non-compliance of their competence level, of the modern mining requirements.

2. Our study developed fundamentals of complex estimation methodology for training quality and proposed a list of key indicators that determine the efficiency of the operators, which differ from the previously known possibility of comprehensive and continuous monitoring of the control system components in the field of training within the general concept of the mining enterprise sustainable functioning.

3. A pilot testing methodologies was carried out for a comprehensive assessment of the training quality of mining machinery and transport-technological complexes operators on the basis of the integral index $\left(\mathrm{k}_{\mathrm{ef}}\right)$, comprehensively taking into account the professional skills, qualifications and work performance.

\section{References}

1. Doktrina natsional'noy bezopasnosti RF [Homeland security doctrine of the Russian Federation], Moscow.

2. Energeticheskaya strategiya Rossii na period do 2013 goda [Energy Strategy of Russia for the period till 2030], Moscow.

3. S.P. Reshetnyak, A.V. Samolazov, N.I. Paladeyeva Burovoye $i$ gorno transportnoye oborudovaniye zhelezorudnykh kar'yerov Rossii $i$ stran SNG. Gornaya promyshlennost'. 5, 18 (2009).

4. K.YU Anistratov, Razrabotka metoda formirovaniya struktury kompleksnoy mekhanizatsii gornykh rabot na kar'yerakh, Abstract of thesis. Apatity, 43 (2013)

5. L.I. Andreyeva, Metodologiya formirovaniya tekhnicheskogo servisa gorno-transportnogo oborudovaniya na ugledobyvayushchem predpriyatii, (Doctoral thesis, Ekaterinburg, 2004)

6. Strategii razvitiya sistemy podgotovki rabochikh kadrov i formirovaniya prikladnykh kvalifikatsiy $v$ Rossiyskoy Federatsii na period do 2020 goda (Moscow, 2015)

7. R.A. Fayzrakhmanov, I.S. Polevshchikov, Analiz metodov $i$ sredstv avtomatizatsii protsessa obucheniya operatorov proizvodstvennotekhnologicheskikh sistem (na primere operatorov peregruzochnykh mashin, Sovremennyye problemy nauki i obrazovaniya 5, (2013) URL: scienceeducation.ru/111-10494.
8. I.SH. Zagretdinov, S.I. Magid, O.B. Danilov et al. Realizatsiya novykh tekhnologiy dlya trenazherov $i$ obuchayushchikh sistem Kharanorskoy GRES, Energosberezheniye i vodopodgotovka. 2, (2004)

9. L.A. Proshkina, Razrabotka kontseptual'noy skhemy obespecheniya konkurentnosposobnogo funktsionirovaniya predpriyatiy trenazherostroyeniya, Nadezhnost' i kachestvo 2008. Trudy mezhdunarodnogo simpoziuma 457 (2008)

10. V.S. Velikanov, Testovyye metodiki i trenazhernyye sredstva $v$ sisteme povysheniya professional'nogo masterstva operatorov gornykh mashin, Gornyy zhurnal 9, 131 (2012)

11. V.S. Velikanov, E.A. Ilina, N.V Dyorina, Obosnovaniye konstruktivnykh i skhemnykh resheniy upravleniya ergonomichnost'yu kar'yernykh ekskavatorov, Procedia Engineering. 150, 1215 (2016)

12. V.S Velikanov, Metodika otsenki professional'noy kompetentnosti operatorov gorno-transportnykh mashin, Gornaya promyshlennost' 2, 114 (2012)

13. V.S. Velikanov, A.A. Shabanov, Otsenka professional'noy kompetentnosti operatorov gornotransportnykh mashin $v$ usloviyakh nechetkoy informatsii, Perspektivy razvitiya gornotransportnogo oborudovaniya: Sbornik statey. Otdel'nyy vypusk Gornogo informatsinnoanaliticheskogo byulletenya, Moscow: Publishing House "Mountain Book". 2, 117 (2012)

14. N.A. Osintsev, Safety management of production in the workplace with the application of the apparatus of the theory of fuzzy sets, Vestnik of NMSTU 4, 83 (2008) 